\title{
PENGARUH SUMBER DAYA MANUSIA, PEMANFAATAN TEKNOLOGI INFORMASI, DAN PENGENDALIAN INTERN AKUNTANSI TERHADAP KETERANDALAN PELAPORAN KEUANGAN PEMERINTAH DAERAH PADA SKPD PEMERINTAH KOTA BUKITTINGGI
}

\author{
Sri Asyrafil Mustaqmah ${ }^{1)}$, Jennisa Dwina Indriana ${ }^{2)}$, dan Mery Triana ${ }^{3)}$ \\ Institu Teknologi dan Bisnis Haji Agus Salim Bukittinggi, Indonesia \\ email: ${ }^{1}$ mustaqmah09@gmail.com \\ 2jennisaadwindriani@gmail.com \\ 3.merytriana@gmail.com
}

\begin{abstract}
This study aims to determine the Effect of Human Resources, Utilization of Information Technology, and Accounting Internal Control on the Reliability of Local Government Financial Reporting. This research was conducted at the SKPD of the Bukittinggi City Government. The technique of determining the sample using purposive sampling technique Sampling is done by taking samples from the population based on certain criteria. The sample criteria taken in this study were employees who carried out financial management in each Regional Apparatus Work Unit as many as 84 people. The type of data used is primary data. The method of data collection is done by questionnaire. The data analysis technique used multiple regression analysis using the SPSS version 22 program. The results showed that Human Resources, Utilization of Information Technology and Accounting Internal Control had a positive and significant effect at partial or simultaneously on the Reliability of Local Government Financial Reporting.
\end{abstract}

Keywords: accounting internal control; human resources; information technology; reliability of local government financial reporting.

\begin{abstract}
ABSTRAK
Penelitian ini bertujuan untuk mengetahui Pengaruh Sumber Daya Manusia, Pemanfaatan Teknologi Informasi, dan Pengendalian Intern Akuntansi Terhadap Keterandalan Pelaporan Keuangan Pemerintah Daerah. Penelitian ini dilakukan Pada SKPD Pemerintah Kota Bukittinggi. Teknik penentuan sampel menggunakan teknik purposive sampling Pengambilan sampel dilakukan dengan mengambil sampel dari populasi berdasarkan suatu kriteria tertentu. Kriteria sampel yang diambil dalam penelitian ini adalah pegawai yang melaksanakan pengelolaan keuangan pada setiap Satuan Kerja Perangkat Daerah sebanyak 84 orang. Jenis data yang digunakan adalah data primer. Metode pengumpulan data dilakukan dengan kuesioner. Teknik analis data menggunakan analisis regresi berganda dengan menggunakan program SPSS versi 22. Hasil penelitian menunjukkan bahwa Sumber Daya Manusia, Pemanfaatan Teknologi Informasi dan Pengendalian Intern Akuntansi berpengaruh positif dan signifikan secara parsial maupun simultan terhadap Keterandalan Pelaporan Keuangan Pemerintah Daerah.
\end{abstract}

Kata kunci: keterandalan pelaporan keuangan pemerintah daerah; pengendalian intern akuntansi; sumber daya manusia; teknologi informasi

Detail Artikel:

Diterima: 19 Januari 2022

Disetujui: 5 Februari 2022

DOI: 10.47896/je.v24i2.487 


\section{PENDAHULUAN}

Dalam pengelolaan keuangan Pemerintah Daerah masih banyak laporan keuangan yang belum menyajikan data-data yang sesuai dengan peraturan dan masih terdapat penyimpanganpenyimpangan, hal ini mendorong meningkatnya tuntutan masyarakat terhadap penyelenggaraan pemerintah yang baik untuk menerapkan akuntabilitas publik yaitu melalui laporan keuangan yang dilaksanakan secara periodik. Tuntutan dilaksanakannya akuntabilitas publik mengharuskan pemerintah daerah untuk memperbaiki system pencatatan dan pelaporan keuangan daerah agar informasi yang diperoleh andal, mengingat bahwa keterandalan merupakan salah satu unsur penting yang berkaitan dengan pengambilan keputusan berbagai pihak yang bersangkutan (Mardiasmo, 2002).

Peraturan Pemerintah Nomor 71 (PP No 71) Tahun 2010 disebutkan bahwa keterandalan laporan keuangan akan terpenuhi jika informasi laporan keuangan bebas dari pengertian yang menyesatkan, kesalahan material dan menyajikan setiap fakta secara jujur serta dapat diverifikasi. Informasi yang terdapat dalam laporan keuangan bisa saja relevan, tetapi jika dalam penyajiannya tidak dapat diandalkan maka pengguna informasi tidak akan mempercayai informasi yang disajikan.

Faktor pertama yang mempengaruhi keterandalan penyusunan laporan keuangan daerah adalah sumber daya manusia, terbatasnya pegawai pemerintah yang berlatar belakang pendidikan bidang akuntansi menjadikan kurangnya pemahaman atau penguasaan aparatur Satuan Kerja Perangkat Daerah (SKPD) dalam mengelola keuangan daerah dengan baik dan benar yang mengakibatkan pemborosan bahan, waktu dan tenaga. Oleh karena itu untuk dapat melaksanakan tanggungjawab dan menghasilkan laporan keuangan yang memenuhi karakteristik keterandalan, maka kapasitas sumber daya manusia yang melaksanakan sistem akuntansi sangatlah penting (Karmila dan Darlis, 2012).

Faktor kedua yang mempengaruhi keterandalan pelaporan keuangan daerah adalah pemanfaatan teknologi informasi. Pemerintah Pusat dan Pemerintah Daerah berkewajiban mengembangkan dan memanfaatkan kemajuan teknologi informasi untuk meningkatkan kemampuan mengelola keuangan daerah dan menyalurkan Informasi Keuangan Daerah kepada pelayanan publik, selain itu dengan menggunakan teknologi informasi komputer dalam menghitung dan menyusun laporan keuangan akan lebih cepat, akurat dan konsisten dari pada sistem manual (Indriasari dan Nahartyo, 2008).

Faktor ketiga yang mempengaruhi keterandalan pelaporan keuangan daerah adalah pengendalian intern akuntansi. Untuk meyakinkan publik mengenai keakuratan laporan keuangan yang dibuat oleh pemerintah dibutuhkan sistem pengendalian intern yang optimal. Sebuah sistem pengendalian intern yang baik dapat menekan terjadinya kesalahan dan penyelewengan dalam batas-batas yang dapat dianggap layak, serta dapat menyajikan fakta secara jujur dan dapat diverifikasi.

Penelitian terdahulu tentang keterandalan laporan keuangan Pemerintah Daerah dilakukan oleh Santiadji Mustafa (2010) pada SKPD pemerintah daerah kota Kendari dan Wan Desi Arisandi (2012) pada Satuan Kerja Perangkat Daerah Kabupaten Siak menemukan bahwa Kapasitas SDM berpengaruh negative terhadap keterandalan pelaporan keuangan pemerintah daerah sedangkan pemanfaatan teknologi informasi, dan pengendalian intern akuntansi memiliki pengaruh positif terhadap keterandalan pelaporan keuangan pemerintah daerah.

Penelitian yang dilakukan oleh (Anggraeni, 2014) tentang Faktor-Faktor yang Mempengaruhi Keterandalan Pelaporan Keuangan Pemerintah Daerah menunjukkan bahwa kualitas sumber daya manusia dan pengawasan keuangan daerah berpengaruh positif terhadap keterandalan pelaporan keuangan pemerintah daerah, sedangkan pengendalian intern akuntansi tidak berpengaruh terhadap keterandalan pelaporan keuangan pemerintah daerah.

Penelitian ini memodifikasi model penelitian Anggraeni (2014) dengan menambahkan variable independen yaitu Pemanfaatan Teknologi Informasi Akuntansi, pelaporan keuangan 
daerah sudah seharusnya memanfaatkan teknologi informasi ini. Namun pemanfaatan seringkali belum dapat dilakukan secara maksimal karena belum siapnya sistem dan SDM yang memadai sehingga perlu diteliti apakah daerah sudah mengimplementasikan sistem informasi akuntansinya dengan baik, objek yang diteliti, perubahan perundang-undangan yang berlaku, waktu dan tempat yang berbeda yaitu Pemerintah Daerah Kota Bukittinggi. Peneliti memilih Pemerintah Kota Bukittinggi karena dalam Pengelolaan Keuangan Pemerintah Daerah Kota Bukittinggi menggunakan sistem informasi berbasis teknologi komputer atau website, dimana website yang digunakan pada pemerintah Kota Bukittinggi sering mengalami pergantian dalam beberapa tahun terakhir ini, pada tahun 2019 Sistem yang digunakan adalah Sistem Informasi Pengelolaan Keuangan Daerah (SIPKD), pada tahun 2020 sistem yang digunakan adalah Sistem Informasi Manajamen Daerah (SIMDA) sedangkan pada tahun 2021 diganti lagi dengan Sistem Informasi Pembangunan Daerah (SIPD).

Dalam meningkatkan kinerja pegawai, Pemerintah Kota Bukittinggi melakukan mutasi pegawai pada Satuan Organisasi Perangkat Daerah, sehingga pada beberapa Satuan Organisasi Perangkat Daerah terdapat sumber daya manusia yang mengelola akuntansi dan keuangan yang berlatar belakang pendidikan non ekonomi. Begitu juga dalam hal pengendalian intern akuntansi, masih terdapat kelemahan, ini terlihat dari adanya Satuan Organisasi Perangkat Daerah pada Pemerintah Kota Bukittinggi yang belum mempunyai pemisahan tugas yang jelas dan kuranganya pengawasan dari Pimpinan.

Berdasarkan latar belakang diatas dan adanya inkonsistensi penelitian, maka penulis melakukan penelitian dengan judul "Pengaruh Sumber Daya Manusia, Pemanfaatan Teknologi Informasi, dan Pengendalian Intern Akuntansi Terhadap Keterandalan Pelaporan Keuangan Pemerintah Daerah Pada SKPD Pemerintah Kota Bukittinggi”.

\section{TELAAH LITERATUR}

\section{Pelaporan Keuangan Pemerintah Daerah}

Pelaporan keuangan pemerintah daerah adalah struktur dan proses meliputi segala aspek yang berkaitan dengan bagaimana penyediaan, pelaporan dan penyampaian informasi keuangan suatu pemerintahan disediakan dan dilaporkan untuk mencapai tujuan pelaporan yang akan membantu pencapaian tujuan ekonomi dan sosial (Suwardjono, 2012:110).

Laporan keuangan Pemerintah daerah berdasarkan Peraturan Pemerintah No. 71 Tahun 2010 tentang Standar Akuntansi Pemerintahan terdiri dari :

1. Laporan Realisasi Anggaran

2. Laporan Perubahan Saldo Anggaran Lebih

3. Neraca

4. Laporan Operasional

5. Laporan Perubahan Ekuitas

6. Laporan Arus Kas

7. Catatatan Atas Laporan Keuangan

\section{Keterandalan}

Keterandalan adalah kemampuan informasi untuk memberi keyakinan bahwa informasi tersebut benar atau valid. PP No 71 Tahun 2010 tentang standar akuntansi pemerintahan menyebutkan bahwa keterandalan pelaporan keuangan merupakan informasi dalam laporan keuangan bebas dari pengertian yang menyesatkan dan kesalahan material, menyajikan setiap fakta secara jujur, serta dapat diverifikasi. Informasi mungkin relevan, tetapi jika hakikat atau penyajiannya tidak dapat diandalkan maka penggunaan informasi tersebut secara potensial dapat menyesatkan. 


\section{Sumber Daya Manusia}

Pengertian sumber daya manusia menurut Werther dan Davis (1996) dalam Darno (2010) adalah orang-orang yang siap, mempunyai keinginan dan mampu untuk berkontribusi dalam tujuan organisasi.

Menurut Sulistiyani dalam Kadarisman (2012) mengemukakan tentang pengembangan SDM adalah

1. Memperbaiki kinerja, memutakhirkan keahlian karyawan.

2. Memutakhirkan keahlian karyawan sejalan dengan kemajuan teknologi.

3. Mengurangi waktu belajar karyawan baru.

4. Membantu memecahkan persoalan operasional.

5. Memenuhi kebutuhan pertumbuhan pribadi.

Berdasarkan uraian dapat disimpulkan bahwa sumber daya manusia merupakan bagian utama dalam sebuah system yang dibentuk oleh organisasi dalam menjalankan tugas dan tanggung jawab yang benar untuk mencapai hasil sesuai dengan ketentuan yang telah ditetapkan.

\section{Pemanfaatan Teknologi Informasi}

Teknologi Informasi adalah suatu teknologi yang digunakan untuk mengolah data, termasuk memproses, mendapatkan, menyusun, menyimpan, memanipulasi dalam berbagai cara untuk menghasilkan informasi yang berkualitas, yaitu informasi yang relevan, akurat, dan tepat waktu, yang digunakan untuk keperluan pribadi, bisnis, dan pemerintahan dan merupakan informasi yang strategis untuk pengambilan keputusan (Sutabri, 2014) dalam Suwardiman (2016).

Salah satu system informasi berbasis teknologi komputer atau website di pemerintah Kota Bukittinggi adalah Sistem Informasi Manajemen Daerah (SIMDA).

\section{Pengendalian Intern Akuntansi}

Pengendalian intern meliputi struktur organisasi, metoda, dan ukuran-ukuran yang dikoordinasikan untuk menjaga kekayaan organisasi, mengecek ketelitian dan keterandalan data akuntansi, mendorong efisiensi, dan dipatuhinya kebijakan pimpinan.

Unsur-unsur pokok yang diperlukan dalam menciptakan pengendalian akuntansi yang efektif antara lain (Wahana Komputer, 2003): (a) adanya perlindungan fisik terhadap harta; (b) pemisahan fungsi organisasi yaitu pemisahan fungsi organisasi yang saling berkaitan; (c) adanya jejak audit yang baik; dan (d) sumber daya manusia yang optimal.

\section{Hipotesis}

$\mathrm{H}_{1}$ sumber daya manusia, $\mathrm{H}_{2}$ pemanfaatan teknologi informasi, $\mathrm{H}_{3}$ pengendalian intern akuntansi, berpengaruh terhadap keterandalan pelaporan keuangan pemerintah daerah dan $\mathrm{H}_{4}$ sumber daya manusia, pemanfaatan teknologi Informasi dan pengendalian Intern Akuntansi secara simultan berpengaruh terhadap keterandalan pelaporan keuangan pemerintah daerah.

\section{METODE PENELITIAN}

Penelitian ini menggunakan data primer dengan menggunakan kuesioner yang dibagikan kepada 84 responden pada Satuan Kerja Perangkat Daerah (SKPD) Pemerintah Kota Bukittinggi, dan data sekunder berupa bukti, catatan atau laporan historis yang telah tersusun dalam arsip (data dokumenter) yang dipublikasikan dan yang tidak dipublikasikan.

Populasi penelitian ini adalah Pegawai pada 28 SKPD Pemerintah Kota Bukittinggi dengan Sampel yang diambil adalah 3 orang untuk masing-masing SKPD. Kuesioner disebarkan secara langsung ke 28 SKPD sebanyak 84 eksemplar. Kuesioner yang kembali dan diisi oleh responden berjumlah 78 eksemplar ( $92.8 \%$ ). Tingginya tingkat pengembalian 
(respon rate) dikarenakan kuesioner diserahkan langsung kepada responden di Organisasi Satuan Kerja Perangkat Daerah tersebut.

Variabel dependen dalam penelitian adalah keterandalan pelaporan keuangan daerah diukur menggunakan Indikator sebagai berikut: Laporan keuangan disajikan secara jujur, dapat diperiksa / diverifikasi, dan netralitas. Dan variabel independen yaitu sumber daya manusia, pemanfaatan teknologi informasi dan pengendalian intern akuntansi. Disusun dalam bentuk instrumen angket (skala Likert) dengan 32 pertanyaan. Angket ini terlebih dahulu diuji validitas dan reliabilitas sebelum digunakan dilapangan.

Penelitian juga menggunakan analisis deskriptif berupa TCR yaitu alat analisis yang digunakan untuk mengukur distribusi skor rata - rata dari hasil penyebaran koesioner, Arikunto (2012). Menggunakan uji asumsi klasik yaitu uji normalitas, uji multikolinearitas, uji heteroskedastisitas, uji autokorelasi dan analisis regresi berganda, koefisien determinasi (R2), uji parsial (uji t) serta uji simultan F.

\section{HASIL DAN PEMBAHASAN}

\section{Karakteristik Responden}

Untuk memperoleh gambaran tentang karakteristik responden yang akan diteliti, dilakukan pengolahan data melalui perhitungan statistik deskriptif. Berikut ini disajikan hasil analisis statistik deskriptif yang diperoleh dari jawaban responden atas pertanyaan yang diajukan oleh peneliti.

1. Deskripsi responden berdasarkan gender menghasilkan responden laki-laki sebanyak 17 orang lebih kecil $21,8 \%$ dibandingkan dengan jumlah responden perempuan yang berjumlah 61 orang $(78.2 \%)$.

2. Deskripsi responden berdasarkan lama kerja menunjukan bahwa responden memiliki masa kerja 1 - 5 tahun yang terbanyak dari responden dengan masa kerja diatas 5 tahun.

3. Deskripsi responden berdasarkan pendidikan terakhir menunjukan jumlah responden yang pendidikan terakhirnya sarjana yang lebih banyak sebesar 53,8\%.

4. Deskripsi responden berdasarkan jabatan menunjukan jumlah responden terbanyak adalah yang menduduki posisi staf akuntansi/keuangan.

\section{Pengujian Validitas dan Reliabilitas}

Uji Validitas

Dari hasil penelitian dan perhitungan koefisien korelasi dapat dikatakan valid karena $\mathrm{R}$ hitung lebih besar dari pada $\mathrm{R}$ tabel dan layak untuk dilakukan penelitian selanjutnya.

\section{$\underline{\text { Uji Reliabilitas }}$}

\section{Tabel 1}

Uji Reliabilitas

\begin{tabular}{llll}
\hline \multicolumn{1}{c}{ Variabel } & Cronbach Alpha & Reliabel & Keterangan \\
\hline Sumber Daya Manusia & 0,861 & 0.60 & Reliabel \\
Pemanfaatan Teknologi Informasi & 0,827 & 0.60 & Reliabel \\
Pengendalian Intern Akuntansi & 0,841 & 0.60 & Reliabel \\
Keterandalan Pelaporan Keuangan & 0,904 & 0.60 & Reliabel \\
\hline
\end{tabular}

Sumber: data yang diolah SPSS 22

Dari hasil penelitian yang penulis lakukan terhadap 78 responden di peroleh hasilnya dari item pernyataan 1 sampai 32 pada variabel Sumber Daya Manusia, Pemanfaatan Teknologi Informasi, Pengendalian Intern Akuntansi, dan Keterandalan Pelaporan Keuangan diperoleh informasi bahwa nilai lebih besar dari 0.60, sehingga dapat di simpulkan bahwa penelitian ini dapat di lanjutkan untuk pengujian selanjutnya. 


\section{Uji Total Capaian Responden} penelitian :

Berikut ini akan dideskripsikan jawaban responden terhadap masing-masing variabel

Variabel sumber daya manusia (X1) terdiri dari 10 indikator pertanyaan. Tanggapan responden yang diperoleh memiliki nilai rata-rata sebesar 4.05 dengan total capaian responden $81 \%$ dan kriteria ini masuk dalam kategori baik.

Variabel pemanfaatan teknologi informasi (X2) terdiri dari 7 indikator pertanyaan. Tanggapan responden yang diperoleh memiliki nilai rata-rata sebesar 4.24 dengan total capaian responden $85 \%$ dan kriteria ini masuk dalam kategori baik.

Variabel pengendalian intern akuntansi (X3) terdiri dari 9 indikator pertanyaan. Tanggapan responden yang diperoleh memiliki nilai rata-rata sebesar 4.18 dengan total capaian responden $83 \%$ dan kriteria ini masuk dalam kategori baik.

Variabel keterandalan pelaporan keuangan (Y) terdiri dari 6 indikator pertanyaan. Tanggapan nresponden yang diperoleh memiliki nilai rata-rata sebesar 4.24 dengan total capaian responden $85 \%$ dan kriteria ini masuk dalam kategori baik.

\section{Pengujian Asumsi Klasik}

\section{$\underline{\text { Uji Normalitas }}$}

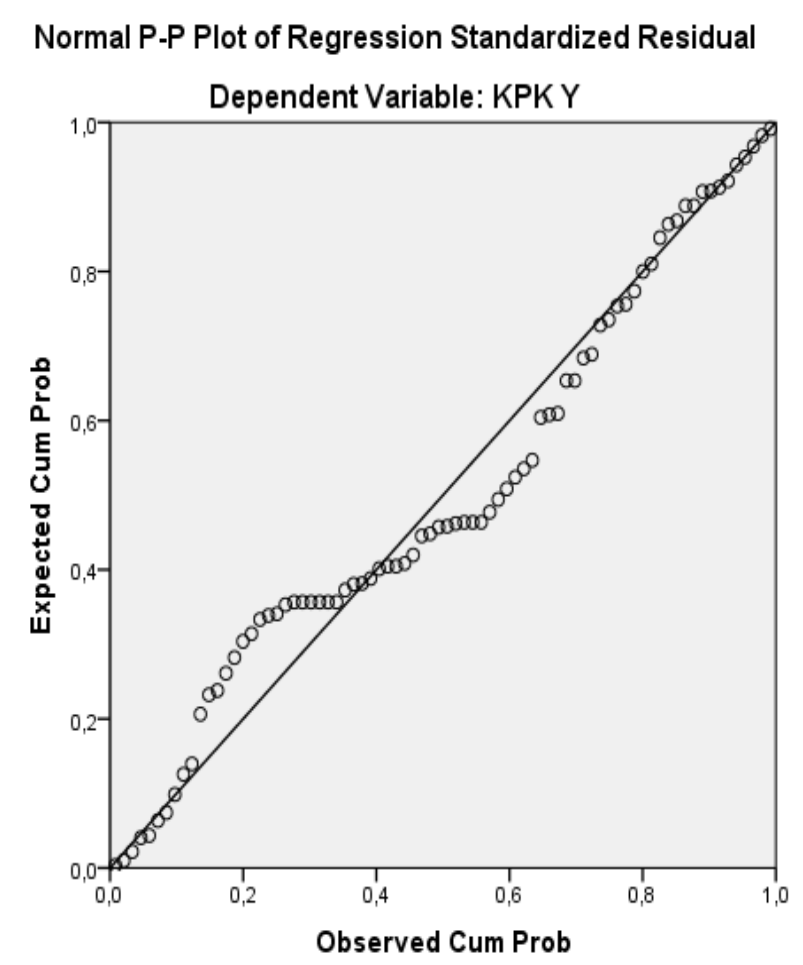

Gambar 1

Uji Normalitas

Sumber: data yang diolah SPSS 22

Berdasarkan tampilan output di atas dapat melihat grafik histrogram maupun grafik plot. Dimana grafik histrogram memberikan pola distribusi yang artinya adalah data berdistribusi normal. Selanjutnya, pada gambar P-Plot terlihat titik-titik mengikuti dan mendekati garis diagonal sehingga dapat disimpulkan bahwa model regresi memenuhi asumsi normalitas. 
Coefficients $^{\mathbf{a}}$

Tabel 2

Uji Multikolinearitas

\begin{tabular}{|c|c|c|c|c|c|c|c|}
\hline \multirow[b]{2}{*}{ Model } & \multicolumn{2}{|c|}{$\begin{array}{l}\text { Unstandardized } \\
\text { Coefficients }\end{array}$} & \multirow{2}{*}{$\begin{array}{c}\begin{array}{c}\text { Standardized } \\
\text { Coefficients }\end{array} \\
\text { Beta } \\
\end{array}$} & \multirow[b]{2}{*}{ t } & \multirow[b]{2}{*}{ Sig. } & \multicolumn{2}{|c|}{$\begin{array}{c}\text { Collinearity } \\
\text { Statistics }\end{array}$} \\
\hline & B & Std. Error & & & & Tolerance & VIF \\
\hline 1 (Constant) & 4,959 & 2,094 & & 2,368 & 0,021 & & \\
\hline SDM X1 & 0,101 & 0,050 & 0,202 & 2,030 & 0,046 & 0,589 & 1,697 \\
\hline PTI X2 & 0,278 & 0,090 & 0,339 & 3,089 & 0,003 & 0,485 & 2,063 \\
\hline PIA X3 & 0,217 & 0,070 & 0,328 & 3,086 & 0,003 & 0,517 & 1,933 \\
\hline
\end{tabular}

a. Dependent Variable: KPK Y

Sumber: data yang diolah SPSS 22

Berdasarkan table uji multikolinearitas diatas, dapat diketahui bahwa antar variabel bebas tidak terjadi multikolinearitas, sebab hasil perhitungan nilai tolerance dari tiap variabel independen tidak ada yang menunjukkan hasil kurang dari 0,10 dan hasil perhitungan nilai variance inflation factor (VIF) juga menunjukkan hasil tiap variabel independen tidak ada yang lebih dari 10. Dapat disimpulkan bahwa tidak terdapat multikolinearitas pada antar variabel independen dalam model regresi ini.

\section{Uji Heteroskedastisitas}

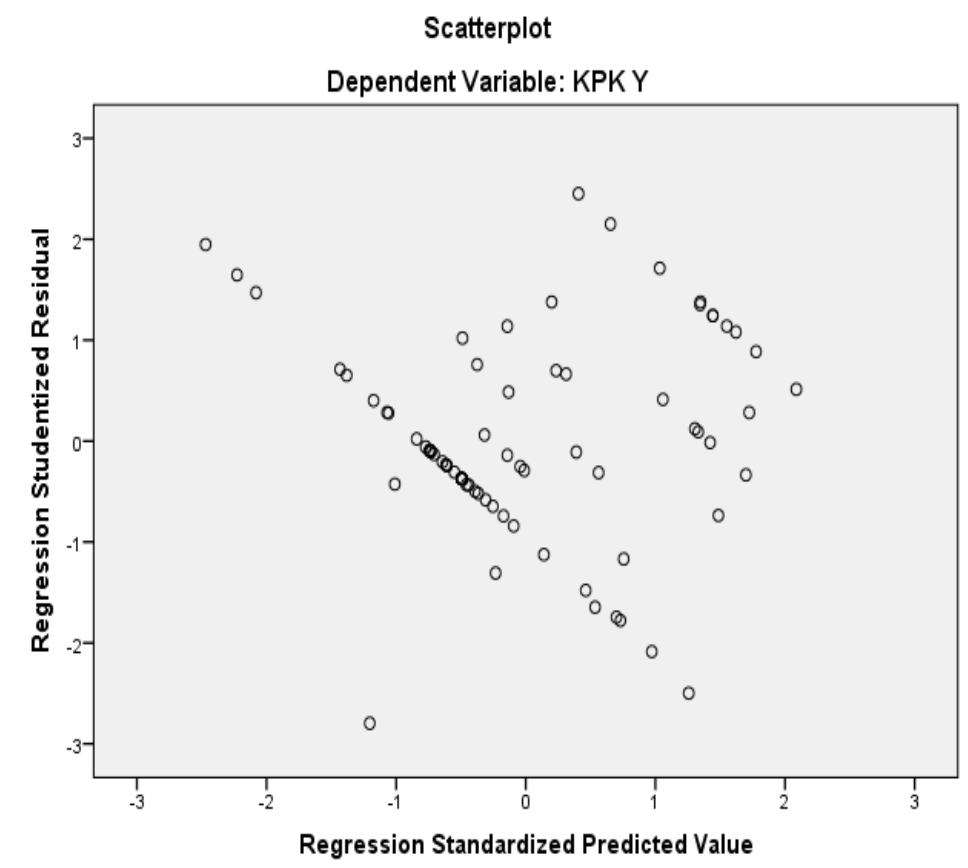

Gambar 2

Uji Heterokedastisitas

Sumber: data yang diolah SPSS 22

Berdasarkan Gambar 2 hasil uji heteroskedastisitas diatas menunjukkan bahwa model regresi tidak mengandung adanya gejala heteroskedastisitas. Dapat dilihat dari titik-titik yang 
menyebar secara acak diatas dan di bawah angka 0 pada sumbu Y dan tidak membentuk pola tertentu, sehingga dapat disimpulkan bahwa model regresi ini tidak terdapat gejala heteroskedastisitas.

\section{Uji Autokorelasi}

Tabel 3

Model Summary ${ }^{\mathrm{b}}$

\section{Uji Autokorelasi}

\begin{tabular}{lllcll}
\hline Model & R & R Square & $\begin{array}{c}\text { Adjusted R } \\
\text { Square }\end{array}$ & $\begin{array}{c}\text { Std. Error of } \\
\text { the Estimate }\end{array}$ & Durbin-Watson \\
\hline 1 &, $754^{\mathrm{a}}$ &, 568 &, 550 & 1,59456 & 1,842
\end{tabular}

a. Predictors: (Constant), PIA X3, SDM X1, PTI X2

b. Dependent Variable: KPK Y

Sumber: data yang diolah SPSS 22

Dari hasil pengujian Autokorelasi pada tabel di atas, menunjukkan bahwa nilai DurbinWatson sebesar 1,842 yang berarti nilai tersebut di antara -2 sampai dengan +2 maka tidak autokorelasi atau bebas dari autokorelasi dalam penelitian ini.

Analisis Regresi Berganda

Tabel 4

Analisis Regresi Berganda

Coefficients $^{\mathrm{a}}$

\begin{tabular}{|c|c|c|c|c|c|c|c|}
\hline \multirow[b]{2}{*}{ Model } & \multicolumn{2}{|c|}{$\begin{array}{c}\text { Unstandardized } \\
\text { Coefficients } \\
\end{array}$} & \multirow{2}{*}{$\begin{array}{c}\begin{array}{c}\text { Standardized } \\
\text { Coefficients }\end{array} \\
\text { Beta } \\
\end{array}$} & \multirow[b]{2}{*}{$\mathbf{T}$} & \multirow[b]{2}{*}{ Sig. } & \multicolumn{2}{|c|}{$\begin{array}{c}\text { Collinearity } \\
\text { Statistics }\end{array}$} \\
\hline & B & $\begin{array}{l}\text { Std. } \\
\text { Error }\end{array}$ & & & & Tolerance & VIF \\
\hline 1 (Constant) & 4,959 & 2,094 & & 2,368 & ,021 & & \\
\hline SDM X1 &, 101 &, 050 & ,202 & 2,030 & ,046 &, 589 & 1,697 \\
\hline PTI X2 & ,278 & ,090 & ,339 & 3,089 & ,003 & ,485 & 2,063 \\
\hline PIA X3 &, 217 &, 070 & ,328 & 3,086 & ,003 &, 517 & 1,933 \\
\hline
\end{tabular}

a. Dependent Variable: KPK Y

Sumber: data yang diolah SPSS 22

Berdasarkan tabel di atas hasil analisis regresi berganda di atas diperoleh persamaan sebagai berikut:

$$
\mathrm{Y}=4.959+0.101 \mathrm{X}_{1}+0.278 \mathrm{X}_{2}+0.217 \mathrm{X}_{3}
$$

Dilihat dari persamaan diatas maka dapat dijelaskan sebagai berikut:

1. Nilai konstanta sebesar 4.959, artinya bila variabel bebas Sumber Daya Manusia, Pemanfaatan Teknologi Informasi dan Pengendaliam Intern Akuntansi dianggap konstan maka dapat diprediksi Keterandalan Pelaporan Keuangan 4.595 satuan.

2. Sumber Daya Manusia (X1) diatas nilai koefisien sebesar 0.101 artinya apabila nilai variabel Sumber Daya Manusia meningkat sebesar 1 satuan dan yang lain konstan, maka dapat diprediksi nilai variabel kinerja keuangan naik sebesar 0.101.

3. Pemanfaatan Teknologi Informasi (X2) memiliki nilai koefisien sebesar 0.278 , artinya apabila nilai variabel Pemanfaatan Teknologi Informasi meningkat sebesar 1 satuan dan yang lain konstan, maka dapat diprediksi nilai variabel Pemanfaatan Teknologi Informasi naik sebesar 0.278 . 
4. Pengendaliam Intern Akuntansi (X3) memilikis nilai koefisien sebesar 0.217, artinya apabila nilai variabel Pengendaliam Intern Akuntansi meningkat sebesar 1 satuan dan yang lain konstan, maka dapat diprediksi nilai variabel kinerja keuangan naik sebesar 0.217.

\section{Uji t}

Uji statistik t dikenal juga sebagai uji signifikasi. Uji signifikansi koefisien regresi parsial secara individu merupakan suatu uji untuk menguji apakah nilai dari koefisien regresi parsial secara individu bernilai nol atau tidak. Cara pengambilan keputusan dapat dilakukan dengan membandingkan nilai probabilitas $p$ atau Sig. dengan nilai tingkat signifikansi, yakni $\alpha$. Jika nilai probabilitas $p \geq$ tingkat signifikansi yang digunakan, dalam penelitian ini $\alpha=5 \%$.

Tabel 5

Uji Hipotesis (t-test)

Coefficients $^{\mathrm{a}}$

$\begin{array}{ccc}\begin{array}{c}\text { Unstandardized } \\ \text { Coefficients }\end{array} & \begin{array}{c}\text { Standardized } \\ \text { Coefficients }\end{array} & \text { Collinearity } \\ \text { Statistics }\end{array}$

\begin{tabular}{|c|c|c|c|c|c|c|c|c|}
\hline & Model & \multirow{2}{*}{$\frac{\text { B }}{4,959}$} & \multirow{2}{*}{$\frac{\text { Std. Error }}{2,094}$} & Beta & \multirow{2}{*}{$\frac{\mathbf{T}}{2,368}$} & \multirow{2}{*}{$\frac{\text { Sig. }}{, 021}$} & \multirow[t]{2}{*}{ Tolerance } & \multirow[t]{2}{*}{ VIF } \\
\hline & (Constant) & & & & & & & \\
\hline 1 & SDM X1 &, 101 & ,050 & ,202 & 2,030 & ,046 & ,589 & 1,697 \\
\hline & PTI X2 & ,278 & ,090 & ,339 & 3,089 & ,003 & ,485 & 2,063 \\
\hline & PIA X3 & ,217 & ,070 & ,328 & 3,086 & ,003 & ,517 & 1,933 \\
\hline
\end{tabular}

a. Dependent Variable: KPK Y

Sumber: data yang diolah SPSS 22 berikut:

Berdasarkan tabel diatas menunjukkan hasil penelitian untuk uji t adalah sebagai

1. Sumber Daya Manusia mempunyai nilai signifikan sebesar $0.046<0.05$, artinya bahwa Sumber Daya Manusia memiliki pengaruh terhadap Keterandalan Pelaporan Keuangan.

2. Pemanfaatan Teknologi Informasi mempunyai nilai signifikan sebesar $0.003<0.05$, artinya bahwa Pemanfaatan Teknologi Informasi memiliki pengaruh terhadap Keterandalan Pelaporan Keuangan.

3. Pengendaliam Intern Akuntansi mempunyai nilai signifikan sebesar $0.003<0.05$, artinya bahawa Pengendaliam Intern Akuntansi memiliki pengaruh terhadap Keterandalan Pelaporan Keuangan.

Uji Simultan (F-test)

Tabel 6

Uji F (F-Test)

ANOVA $^{\mathrm{a}}$

\begin{tabular}{llllllc}
\hline \multicolumn{1}{c}{ Model } & \multicolumn{1}{c}{ Sum of Squares } & df & Mean Square & F & Sig. \\
\hline 1 & Regression & 247,294 & 3 & 82,431 & 32,420 &, $000^{\mathrm{b}}$ \\
Residual & 188,155 & 74 & 2,543 & & \\
\cline { 2 - 3 } & 435,449 & 77 & & & \\
\hline
\end{tabular}

a. Dependent Variable: KPK Y

b. Predictors: (Constant), PIA X3, SDM X1, PTI X2

Sumber: data yang diolah SPSS 22

Berdasarkan tabel diatas menujukan bahwa nilai signifikansi lebih kecil dari pada 0.05 , sehingga dapat disimpulkan bahwa masing-masing variabel independen (Sumber Daya 
Manusia, Pemanfaatan Teknologi Informasi dan Pengendalian Intern Akuntansi) secara bersama-sama berpengaruh terhadap variabel dependen (Keterandalan Pelaporan Keuangan).

\section{Uji Koefisien Determinasi $\left(\mathbf{R}^{2}\right)$}

Tabel 7

Uji Koefisien Determinasi

Model Summary ${ }^{b}$

\begin{tabular}{llllll}
\hline Model & $\mathbf{R}$ & R Square & $\begin{array}{c}\text { Adjusted R } \\
\text { Square }\end{array}$ & $\begin{array}{c}\text { Std. Error of } \\
\text { the Estimate }\end{array}$ & Durbin-Watson \\
\hline 1 &, $754^{\mathrm{a}}$ &, 568 &, 550 & 1,59456 & 1,842 \\
\hline
\end{tabular}

a. Predictors: (Constant), PIA X3, SDM X1, PTI X2

b. Dependent Variable: KPK Y

Sumber: data yang diolah SPSS 22

Berdasarkan pada tabel di atas hasil uji koefisien determinasi $\left(\mathrm{R}^{2}\right)$ diatas menunjukkan nilai Adjusted $\mathrm{R}$ Square $\left(\mathrm{R}^{2}\right)$ sebesar 0.568. Hal ini menunjukkan bahwa variabel dependen Keterandalan Pelaporan Keuangan dapat dijelaskan oleh variabel dependen Sumber Daya Manusia, Pemanfaatan Teknologi Informasi, dan Pengendaliam Intern Akuntansi sebesar $56,8 \%$, sedangkan sebesar 43,2\% dipengaruhi oleh variabel-variabel lain di luar dari penelitian ini.

\section{Pembahasan}

\section{Pengaruh Sumber Daya Manusia Terhadap Keterandalan Pelaporan Keuangan}

Kapasitas sumber daya manusia berpengaruh positif signifikan terhadap keterandalan pelaporan keuangan pemerintah daerah Kota Bukittinggi. Hal ini berarti bahwa semakin memadai kapasitas sumber daya manusia maka pemerintah Kota Bukittinggi juga akan semakin baik dalam menghasilkan pelaporan keuangan yang andal.

\section{Pengaruh Pemanfaatan Teknologi Informasi Terhadap Keterandalan Pelaporan Keuangan}

Pemanfaatan teknologi informasi berpengaruh positif signifikan terhadap keterandalan pelaporan keuangan pemerintah Daerah Kota Bukittinggi. Hal ini berarti bahwa semakin tingginya pemanfaatan teknologi informasi maka akan meningkatkan kualitas informasi yang dihasilkan dalam pelaporan keuangan yang menjadi lebih andal. Pemanfaatan teknologi informasi yang dimaksud seperti penggunaan komputer dan perangkat lunak secara optimal, akan berdampak pada pemprosesan transaksi yang lebih cepat dan perhitungannya juga akan memiliki tingkat keakurasiaan yang tinggi sehingga akan berujung pada peningkatan kualitas pelaporan keuangan yang lebih andal karena pemanfaatan teknologi akan mengurangi kesalahan yang bersifat material.

Pengaruh Pengendalian Intern Akuntansi Terhadap Keterandalan Pelaporan Keuangan Pengendalian intern akuntansi berpengaruh positif signifikan terhadap keterandalan pelaporan keuangan pemerintah Daerah Kota Bukittinggi. Hal ini berarti bahwa semakin baik pengendalian intern akuntansi yang ada maka pemerintah daerah juga akan semakin baik dalam menghasilkan pelaporan keuangan yang andal. Pengendalian intern akuntansi yang baik akan tercermin dalam beberapa hal diantaranya, adanya sistem dan prosedur akuntansi, adanya sistem otorisasi, adanya pemisahan tugas, dan adanya sistem formulir, dokumen dan catatan, yang mana semua hal tersebut akan mendukung fungsi keuangan pada pemerintah daerah dalam menghasilkan pelaporan keuangan yang andal. 
Pengaruh Sumber Daya Manusia, Pemanfaatan Teknologi Informasi dan Pengendalian Intern Akuntansi Terhadap Keterandalan Pelaporan Keuangan Pemerintah Daerah

Masing-masing variabel independen (Sumber Daya Manusia, Pemanfaatan Teknologi Informasi dan Pengendalian Intern Akuntansi) secara bersama-sama berpengaruh signifikan terhadap variabel dependen (Keterandalan Pelaporan Keuangan). Dari pengujian data terlihat bahwa SKPD di Pemerintah Kota Bukittinggi memiliki kualitas sumber daya manusia serta pemanfaatan teknologi informasi yang memadai serta didukung dengan sistem pengendalian intern yang baik. Hal ini dikarenakan pegawainya yang mayoritas merupakan pegawai yang telah memiliki bekal pengetahuan, pelatihan serta pengalaman yang baik di bidang Kualifikasi yang baik dari pegawai sub bagian keuangan ini kemudian dibantu oleh sarana komputer yang memadai serta sudah dilengkapi jaringan internet dan aplikasi pengolahan data akuntansi pemerintah yaitu SIMDA dan SIPD. Hal tersebut mempermudah pegawai dalam penyusunan laporan keuangan. Sistem pengendalian internnya pun sudah dijalankan dengan baik. Salah satunya adalah dengan bukti transaksi yang valid dan sah setiap melakukan kegiatan atau transaksi. Sehingga informasi yang dimasukkan dalam laporan keuangan akan menjadi akurat. Penyajian laporan keuangan yang disusun mengandung informasi yang jujur dan wajar. Sehingga hal tersebut meningkatkan keterandalan pelaporan keuangan pemerintah daerah.

\section{SIMPULAN}

Berdasarkan hasil penelitian dan pembahasan maka dapat diambil kesimpulan dalam penelitian ini sebagai berikut :

a) Kapasitas sumber daya manusia berpengaruh positif signifikan terhadap keterandalan pelaporan keuangan pemerintah daerah Kota Bukittinggi.

b) Pemanfaatan teknologi informasi berpengaruh positif signifikan terhadap keterandalan pelaporan keuangan pemerintah Daerah Kota Bukittinggi.

c) Pengendalian intern akuntansi berpengaruh positif signifikan terhadap keterandalan pelaporan keuangan pemerintah Daerah Kota Bukittinggi.

d) Sumber Daya Manusia, Pemanfaatan Teknologi Informasi dan Pengendalian Intern Akuntansi secara bersama-sama berpengaruh signifikan terhadap Keterandalan Pelaporan Keuangan.

\section{DAFTAR PUSTAKA}

Darno. 2010. Analisis Pengaruh Kemampuan Sumber Daya Manusia Dan Pemanfaatan Teknologi Informasi Terhadap Kualitas Laporan Barang Kuasa Pengguna (Studi pada Satuan Kerja di Wilayah Kerja KPPN Malang). Jurnal Ilmiah Akuntansi.

Halim, Abdul. 2011. Akuntansi Sektor Publik: Akuntansi Keuangan Daerah. Edisi Keempat. Jakarta: Salemba Empat

Harahap. (2011). Analisis Kritis Atas Laporan Keuangan. Jakarta: Raja grafindo Persada.

Hendra Wansyah, Darwanis, Usman Bakar, 2012. Pengaruh Kapasitas Sumber Daya Manusia, Pemanfaatan Teknologi Informasi Dan Kegiatan Pengendalian Terhadap Nilai Informasi Pelaporan Keuangan Skpd Pada Provinsi Aceh, Jurnal Akuntansi Pascasarjana Universitas Syiah Kuala Volume 1, No. 1, Agustus 2012

Indriasari, Desi dan Ertambang Nahartyo. 2008. Pengaruh Kapasitas Sumber Daya Manusia, Pemanfaatan Teknologi Informasi dan Pengendalian Intern Akuntansi Terhadap Nilai Informasi Pelaporan Keuangan Pemerintah Daerah (Studi pada Pemerintah Kota Palembang dan Kabupaten Ogan Illir). Kumpulan Makalah Simposium Nasional Akuntansi XI. 23-24 Juli.

Mardiasmo, 2002. Akuntansi Sektor Publik. Penerbit Andi Yogyakarta.

----------------, Peraturan Pemerintah Nomor 71 Tahun 2010 tentang Standar Akuntansi Pemerintahan 
Suwardjono. 2012. Teori Akuntansi: Perekayasaan Pelaporan Keuangan. Edisi Ketiga. BPFE, Yogyakarta.

Wahana Komputer. 2003. Panduan Aplikatif Sistem Akuntansi Online Berbasis Komputer. Penerbit ANDI, Yogyakarta.

Wilkinson, W. Joseph, Michael J. Cerullo, Vasant Raval, \& Bernard Wong-On-Wing. 2000. Accounting Information Systems: Essential Concepts and Applications. Fourth Edition. John Wiley and Sons. Inc. 